\title{
APRESENTAÇÃO DE UM JOVEM ESCRITOR José de Alencar nos ensaios literários
}

\author{
José Quintão de Oliveira” \\ jqpjqo@yahoo.com.br
}

Recorda José de Alencar: "Fundamos, os primeiranistas de 1846, uma revista semanal sob o título de Ensaios Literários."' (1995, p. 32). Essa publicação circulou em São Paulo onde o escritor cursou Direito, entre setembro de 1847 e 1850; era veículo do Instituto Literário Acadêmico - a Associação de Acadêmicos que às vezes acompanha o título -, fundada pelos calouros de 1846. A publicação teve entre seus colaboradores, além do escritor, várias outras importantes figuras do período romântico como Álvares de Azevedo, Bernardo Guimarães, Joaquim Felício dos Santos e José Bonifácio, entre outros. O autor de Iracema, por sua vez, menciona alguns fundadores e colaboradores da revista que deixaram marca pequena nas letras.

Essa publicação acadêmica, tão característica daquele período, deve ser lembrada não somente pelos nomes dos seus colabores e ilustre fundador, mas também porque esse ali teve suas primícias literárias.

\footnotetext{
* Professor de literatura brasileira, pesquisador do IEB/USP. Estudo produzido sob o amparo de uma bolsa de pós-doutorado oferecida pela FAPESP.

1 Foram utilizados microfilmes e pranchas fotográficas fornecidas pela Biblioteca Nacional, que possui no seu acervo alguns números da revista. Fica aqui consignado o devido agradecimento, destacando-se a gentileza do atendimento propiciado pelo corpo funcional da FBN.
} 
Nessa revista, Alencar publicou três pequenos ensaios, dois deles apenas parcialmente dados à luz, nunca foram completados. Ou, melhor dizendo, nunca foram encontradas suas partes faltantes, já que a revista, dita semanal por Alencar, seria, ao que tudo indica, mensal (essa indicação aparece na cimalha de algumas capas), embora irregular, dadas as dificuldades enfrentadas por esse tipo de publicação. Há notícias de treze edições (GARMES, 1993), talvez seja esse todo o material publicado, talvez haja mais, não é possível, por enquanto, fazer uma afirmação definitiva.

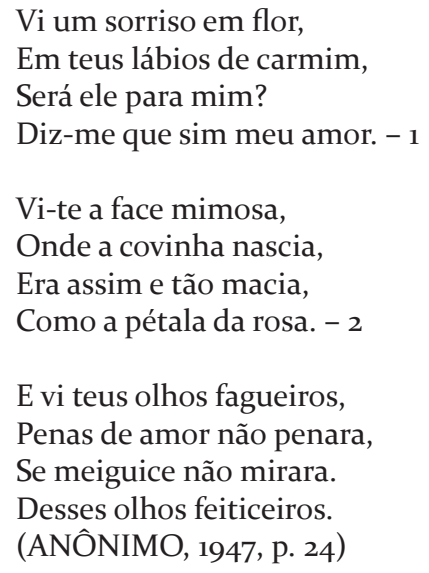

Os versos acima - uma charada, cuja solução, Elisa, o leitor saberá no número da revista seguinte a esse - circularam sem indicação de autoria na edição inaugural dos Ensaios Literários. Alencar se declara em Como e porque sou romancista um praticante desse gênero de literatura durante o seu aprendizado da escrita literária. Chega mesmo a afirmar que " $\mathrm{O}$ dom de produzir e a faculdade criadora, se a tenho, foi a charada que a desenvolveu em mim" (ALENCAR, 1995, p. 24). Esse passatempo literário constituía uma das seções fixas da revista. ${ }^{2}$ Deve-se observar ainda que três publicações em 13 números de uma revista que cobriu um período de quatro anos parecem número excessivamente modesto considerando-se a produtividade do escritor. A essa produtividade sabida, pode-se acrescer a provável ânsia de publicidade para quem, como ele, tanto sonhava com a glória das letras. Unindo-se essas informações e observações talvez se possa especular sobre a autoria das charadas, apresentando o escritor

2 Maiores informações e uma extensa análise dessa publicação podem ser obtidas na dissertação de Hélder Garmes (1993). 
como um candidato; não parece haver elementos positivos que abonem essa especulação, fica, porém, anotada, como uma possibilidade a ser aferida por trabalhos posteriores.

O primeiro dos ensaios - A carnaúba - saiu à luz em 1848; o segundo - Sobre a vida de D. Antônio Felipe Camarão - em 1849 e o terceiro $\mathrm{O}$ estilo na literatura brasileira, em 1850. Os três permaneceram praticamente inéditos, não sendo sequer de conhecimento da maioria dos estudiosos da obra do autor. Apenas no período mais recente foram localizados e passaram a ser mencionados, muitas vezes sem muita convicção sobre a sua localização. À frente estão reunidas essas primeiras publicações de José de Alencar, vindas à luz entre 1848 e 1850. São textos curtos, produzidos todos no período acadêmico do escritor, que concluiu o curso de Direito em 1850. Nenhum deles deve ser estritamente considerado uma obra literária. São, porém, importantes por constituírem as primeiras publicações do escritor de que se tem notícia, permitindo ao estudioso ou interessado verificar como se deu caracteristicamente a evolução da escrita do autor, como se formou e se transformou a sua maneira, o seu estilo.

O primeiro desses textos - A carnaúba -, aparece posto sob o título geral de Botânica, a indicar talvez a intenção de uma seção dedicada ao tema. Foi publicado em 1848 e é o único dos três textos apresentados à frente que não traz uma indicação gráfica de continuação. Vislumbra-se ali o Alencar observador da natureza, mais que isso, o observador em sentido geral, dedicado à análise e ao estudo, que se patenteará integralmente mais tarde nas obras do ficcionista. Está assinado por Al. (Sócio Corresp.), provavelmente enviado para publicação (ou ao menos publicado) no período em que o escritor esteve fora de São Paulo. O texto, num recorte bastante científico, exibe conhecimentos hauridos nos livros e manuais, mas explicita também a observação direta e o inquérito de quem muito provavelmente se informou com os conhecedores da palmeira de folhas "alequeadas verdes, glabras, e lisas", como a descreve.

É difícil não lembrar do talhe de palmeira de Iracema quando se lê que a carnaúba tem o "tronco delgado, esbelto, e direito", que suas folhas "imitam o murmúrio do regato, quando a viração roça por elas". Trecho em que quase se antecipa a voz da bela Tabajara: "Enterra o corpo de tua esposa ao pé do coqueiro que tu amavas. Quando o vento do mar soprar nas folhas, Iracema pensará que tua voz que fala entre seus cabelos." (ALENCAR, 1965. p. 136). Pode-se vislumbrar já nesse despretensioso 
estudinho - tomando-se o termo a José Veríssimo - o comparatismo que será tão magistralmente utilizado na lenda do Ceará. Entrevê-se o narrador que com tanta força descreve a natureza já em formação em trechos como o parágrafo inicial - "A carnaúba pertence à bela e majestosa família das palmeiras; é linda de ver-se, quando reverdece com as primeiras águas do inverno" -, destacando-se a parte que se inicia por "Tem uma força de vegetação robusta e poderosa [...] nestes tempos de longa e ardente seca, quando entra a calma por nossas planícies áridas, quando nem orvalho verte do céu". Em variados outros momentos será possível ao leitor atento surpreender o nascimento dos recursos que o autor maduro manipulará à farta.

Segundo Araripe Júnior, durante essa estada em Olinda nasceram os romancetes $A$ alma do Lázaro e $O$ ermitão da Glória, que seriam muitos anos mais tarde revistos pelo autor e dados à publicidade (ARARIPE JÚNIOR, 1958). Na abertura do livro que acolhe as duas obras Alfarrábios - há um texto intitulado Cavaco, que parece confirmar a nota de Araripe: "O Garatuja é a primeira de uma série de crônicas dos tempos coloniais, algumas já escritas, outras apenas esboçadas, dos tempos idos” (ALENCAR, 1951a, p. 25). Na abertura do último desses alfarrábios, A alma do Lázaro, chama-o "uma escavação dos tempos escolásticos." (ALENCAR, 1951a, p. 233). Em Como e porque sou romancista, fala de outra tentativa de romance dos tempos escolares - Os contrabandistas - de que sua Obra completa (ALENCAR, 196o, v. III. pp. 1319-1324) recolhe a pequena parte que sobreviveu ao seu destino de acender os charutos de um hóspede sem muita sensibilidade literária, como relembra no escrito referido.

O segundo ensaio foi publicado quando seu autor já retornara a São Paulo, vindo de Pernambuco, onde cursou o terceiro ano (MENEZES, 1977). É um escorço biográfico de Felipe Camarão, o Poti; se não tem grande interesse como criação literária, pode interessar bastante quando cotejado com a produção do escritor maduro. Ali pode-se perceber que os temas de obras como as anteriormente referidas, As minas de prata e a trilogia indianista e outras já acompanhavam o escritor desde o seu alvorecer. O biografado retornará em Iracema; o motivo histórico se apresentará nessas e em outras obras. E, assim como o primeiro dos três escritos, mostra um jovem estudioso e pesquisador, característica definitiva do criador, que produzirá sempre amparado, de um lado, por sólido conhecimento dos seus instrumentos literários, e de outro, por 
extensas pesquisas e estudos, estruturando sempre uma base sólida de onde parte sua imaginação vertiginosa.

O retrato de Poti que traça o jovem estreante das letras é uma espécie de rascunho daquele que os leitores encontrarão em Iracema: um ameraba cristianizado, portador das qualidades de cavalheirismo e coragem características do herói romântico. "Filho das crenças dos índios, ele renegou sua vida de selvagem liberdade às primeiras palavras dos ministros da religião, - e se fez cristão", diz de Poti o escritor aprendiz de 1849. Dirá da mesma figura o criador consagrado de 1865:

\footnotetext{
Muitos guerreiros de sua raça acompanharam o chefe branco, para fundar com ele a mairi dos cristãos. Veio também um sacerdote de sua religião, de negras vestes, para plantar a cruz na terra selvagem.

Poti foi o primeiro que ajoelhou aos pés do sagrado lenho; não sofria ele que nada mais o separasse de seu irmão branco. Deviam ter ambos um só deus, como tinham um só coração. (ALENCAR, 1965, pp. 137-138)
}

A mesma personagem, as mesmas escolhas, só que ainda mais romantizadas como seria da expectativa numa narrativa da ficção indianista. O que está sem explicação no esboço biográfico é então mostrado numa espécie de forma superlativa no gesto de um homem, que por amor de uma amizade, renuncia aos seus deuses ancestrais. Estão ali, sem dúvida expostas pela primeira vez, as mais antigas florescências do que será o indianismo de José Alencar, ainda mais transparentes no olhar crítico sobre a colonização e na envolvente empatia ofertada ao amerígena: "O elemento militar dominou: - destruiu-se uma nação valente e guerreira, inteligente e industriosa em guerra exterminadora, às vezes iníqua e traiçoeira; - o Brasil comprou a sua colonização com o sangue dos seus filhos, com o ouro de suas entranhas." Observando-se a escrita percebem-se ainda no nascedouro, entre outras características, sestros como a ojeriza ao uso do artigo definido antes dos possessivos, definitiva no escritor maduro.

O terceiro e mais importante destes ensaios - $\mathrm{O}$ estilo na literatura brasileira - traz a assinatura Alencar. Tal como a biografia de Felipe Camarão, estava planejado para uma série, como se depreende do "continua" abaixo da assinatura do autor, muito embora o sumário que se segue ao título aponte apenas para este ensaio. Não se localizou a continuação prometida, mas o excerto publicado já permite bem sondar as concepções linguísticas e literárias do jovem bacharelando de Direito. Esse texto está integralmente reproduzido no livro O império da cortesã, 
da professora Valéria De Marco, publicado como apêndice, em transcrição diplomática. ${ }^{3}$

A estudiosa aponta a mudança da concepção da língua, que nesse ensaio o escritor considera "degenerada pela invasão dos Mouros na Península”, para aquela presente no pós-escrito à Diva e no prefácio a Sonhos d'ouro, que admite e defende como processo legítimo e necessário da língua a inclusão e assimilação das formas de dizer vindas de outros idiomas sempre que forem belas e necessárias à expressão:

Sem o arremedo vil da locução alheia e a imitação torpe dos idiotismos estrangeiros, devem as línguas aceitar algumas novas maneiras de dizer, graciosas e elegantes, que não repugnem ao gênio do organismo. (ALENCAR, 1951, p. 312)

Ou seja, verifica-se a mudança da posição de defensor da pureza da língua - que mais tarde tanto combaterá - à posição que o leva a defender o "progresso em tudo, até mesmo na língua que fala" (ALENCAR, 1951. p. 311), como se dá no pós-escrito ao romance Diva. A partir dessa postura progressista, defende não apenas os termos de origem estrangeira, mas os brasileirismos e os neologismos em geral, orientando-se pela busca por uma expressão literária adequada, conveniente e elegante. A verdade, porém, é que as suas concepções das línguas nacional e literária se apresentam já amadurecidas bem anteriormente a esses escritos, como pode ser constatado nas cartas sobre o poema de Domingos Gonçalves de Magalhães. Ali o escritor vê a língua portuguesa como uma "sonora e doce filha dos romanos poetizada pelos árabes e pelos godos." (ALENCAR, 1856, p. 52). Instrumento do espírito, esta muda à medida que mudam as ideias e costumes do povo que dela se serve. Assim, a despeito dos protestos puristas retrógrados "a língua rompe as cadeias que lhe querem impor, e vai se enriquecendo já de novas palavras, já de outros modos diversos de locução" (ALENCAR, 1951, p. 311), completa o escritor maduro. Deve-se enfatizar ainda que já no ensaio acadêmico Alencar combate os puristas, aliás, esse texto tem por objetivo exatamente combater essa corrente, portugueses à frente, que defende um ideal linguístico calcado sobre os valores do português quinhentista.

3 ALENCAR (José de). O estilo na literatura brasileira. In: MARCO, Valéria De. O império da cortesã: Lucíola: um perfil de Alencar. São Paulo: Martins Fontes, 1986, pp. 201-204. 
Seria interessante, porém, cotejar esse texto da juventude com outros da maturidade, buscando mais que as descontinuidades, as continuidades com os escritos críticos e autocríticos que o escritor produziu no decorrer da sua vida tão breve. O resultado seria certamente o espanto face à solidez de algumas reflexões do estudante, que se manterão como parte integrante das concepções e escolhas estéticas da vida inteira. No escrito de 1850 estão já presentes a pontuação idiossincrática, o gosto pela frase sonora e ritmada, explorando a eufonia e musicalidade da língua portuguesa do Brasil. Estão lá o empenho em favor de uma língua literária nacional, diferenciada e autônoma ante o cânone português e, sintoma da solidez da sua reflexão, o conceito de adequação da linguagem, isto é a harmonia entre a forma e o conteúdo, fundidos numa unidade maior. No posfácio que acrescentou ao romance Diva, o expõe com a segurança da experiência:

\footnotetext{
Não é obrigando-a a estacionar que hão de manter e polir as qualidades que porventura ornem uma língua qualquer; mas sim fazendo que acompanhe o progresso das ideias e se molde às novas tendências do espírito, sem contudo perverter a sua índole abastardar-se. (ALENCAR, 1951, p. 311)
}

Em consequência, o escritor deve ser capaz de criar termos novos quando se fizer necessário, aproveitar aqueles vindos de outras línguas quando adequados e explorar as fontes da sua própria, buscando as preciosidades que podem estar ali perdidas. Essas são as suas tarefas e o verdadeiro classicismo.

$O$ pequeno ensaio do final do período estudantil é, sobretudo, o produto de muito estudo, sugerindo uma permanente busca de domínio dos meios de expressão literária, uma preparação para o futuro que o então veterano estudante de Direito anseia por ver chegar. Lembra-se nesse ponto a menção que faz em Como e porque sou romancista ao lançamento do "gentil romance" - a expressão é dele - de Joaquim Manuel de Macedo em 1844:

Que estranho sentir não despertava em meu coração adolescente a notícia dessas homenagens de admiração e respeito tributados ao jovem autor da Moreninha! Qual régio diadema valia essa auréola de entusiasmo a cingir o nome de um escritor? (ALENCAR, 1995, p. 27)

A partir dessa lembrança, não soa nada espantoso imaginar que o leitor doméstico - condição lembrada neste mesmo livro -, então há 
muito afastado da titularidade da função, tenha nesse período somado ao prazer da leitura a intensiva preparação para os afazeres literários que estão por vir. Parece ser possível localizar - numa jornada em que o curto ensaio literário de 1850 marca um ponto de inflexão -, uma espécie de coerência que se prolonga no tempo unindo o menino ao adulto na figura do escritor, que à inspiração e ao talento natos soube desde cedo somar a preparação e o estudo sistemáticos.

Explicita-se nesses textos de aprendizado o interesse pelos temas nacionais, sejam da natureza ou histórico-sociais. Deve ser apontado no ensaio de 1850 a questão da língua literária nacional em seu nascedouro; a busca do diálogo com os clássicos da literatura de língua portuguesa sem que isso redunde em desprezo pelos escritores da atualidade. Muito ao contrário, aliás, propõe o jovem Alencar uma fruição dupla, são os clássicos e os modernos fontes de prazer estético e exemplos a serem emulados. São parte de uma trajetória precocemente iniciada, tudo indica que guiada por um objetivo definido - tornar-se o primeiro grande escritor brasileiro. Para isso estudou e se preparou o filho do senador Alencar, como se patenteia nos escritos que seguem.

Parece que já se disse o suficiente para uma introdução que não quer ser um estudo crítico sistemático, mas um convite à leitura. Essas pequenas considerações devem, assim, ser vistas não como uma avaliação dos textos apresentados, mas uma provocação, um levantamento de algumas pistas de leitura em desafio à argúcia do leitor. É hora, portanto, de se passar aos escritos de Alencar que são, ao fim, o que realmente importa.

Os três textos que seguem não passaram por uma edição crítica, estão, porém, fidedignamente editados: passaram por uma transcrição minuciosa e criteriosa verificação. Respeitou-se escrupulosamente a escrita autoral, limitando-se a intervenção do organizador à atualização ortográfica, o que, aliás, se aplica também ao material citado. Palavras como "cousa" que à época admitiam dupla grafia - cousa/coisa - foram preservadas como se apresentavam. A pontuação idiossincrática, bem como o uso do travessão foram escrupulosamente respeitados e mantidos. Conhecer o uso que da pontuação fazia o autor neste momento da sua jornada certamente auxiliará na compreensão dos recursos do escritor maduro. As intervenções da edição, limitadas ao indispensável, como as gralhas tipográficas evidentes, estão sempre consignadas em notas numeradas nos rodapés. As notas de responsabilidade de José Alencar estão identificadas pela consigna Nota de Alencar, posta entre colchetes. 
Esses sinais serão usados ainda, sempre que se fizer necessário, para indicar a inserção de sinal ou termo que não consta do original. Preservaramse também as maiúsculas de magnificação e os itálicos. Observe-se que algumas palavras - como se dá com o substantivo índio - às vezes aparecem grafadas com maiúsculas, outras com minúsculas, o que foi mantido.

\section{REFERÊNCIAS BIBLIOGRÁFICAS}

ALENCAR, José de. Como e porque sou romancista. 2. ed. Rio de Janeiro: Academia Brasileira de Letras, 1995.

ALENCAR, José de. Obra completa. 4 v. Rio de Janeiro: José Aguilar, 1959-196o.

ALENCAR, José de. Iracema: lenda do Ceará. Ed. crít. de Manuel Cavalcanti Proença. Rio de Janeiro: José Olympio, 1965.

ALENCAR, José de. Diva. In: Lucíola/Diva. Rio de Janeiro: José Olympio, 1951. pp. 191-323.

ALENCAR, José de. Alfarrábios. Rio de Janeiro: José Olympio, 1951a.

ALENCAR, José de. Cartas sobre A Confederação dos Tamoios. Rio de Janeiro: Empresa Tipográfica Nacional do Diário, 1856.

ALENCAR, José de. O estilo na literatura brasileira. Ensaios literários, Jornal Acadêmico. São Paulo, s. n., pp. 34-36, s. d. [1850].

ALENCAR, José de. Sobre a vida de D. Antônio Felipe Camarão. Ensaios Literários, Jornal Acadêmico. s.n., pp. 8-12, s.d. [1849].

ALENCAR, José de. A carnaúba. Ensaios Literários, Jornal de uma Associação de Acadêmicos. São Paulo, za. série, n. 2, pp. 25-28, abril de 1848.

ANÔNIMO. Charada. Ensaios Literários, Jornal de uma Associação de Acadêmicos, São Paulo, 3a. série, n. 2, p. 23, abril de 1848.

ARARIPE JUNIOR, T. A. José de Alencar. In: . Obra crítica de Araripe Júnior. 5 v. Rio de Janeiro: Casa de Rui Barbosa, 1958. v. I. pp. 129-258.

GARMES, Hélder. Os ensaios literários (1847-1850) e o periodismo acadêmico em São Paulo de 1833 a 1860. (disertação de mestrado). Campinas: Unicamp, 1993. Disponível em: http://www.bibliotecadigital.unicamp.br/document/?code=vtlsoooo64065\&fd=y.

MARCO, Valéria de. O império da cortesã. São Paulo: Martins Fontes, 1986.

MENEZES, Raimundo de. José de Alencar. 2. ed. Rio de Janeiro: LTC, 1977. 


\section{BOTÂNICA \\ A CARNAÚBA}

A carnaúba pertence à bela e majestosa família das palmeiras; é linda de ver-se, quando reverdece com as primeiras águas do inverno: seu tronco delgado, esbelto e direito sobe à altura de 50 palmos e mais no seu estado de perfeito crescimento: - sua ramagem é uma lindíssima coroa de palmas alequeadas - de verde-mar, ${ }^{4}$ que imitam o murmúrio do regato, quando a viração roça por elas. - Esta palmeira multiplicase com facilidade prodigiosa: - nos sertões de Pernambuco e Ceará há várzeas imensas de carnaúbas estendidas por grande distância de léguas, beirando as margens areentas dos córregos, e dos rios. - Tem uma força de vegetação robusta e poderosa, o que atesta além de tudo a sua longa caducidade: nestes tempos de longa e ardente seca, quando entra a calma por nossas planícies áridas, quando nem orvalho verte do céu nas quentes noites do estio, a carnaúba abre suas palmas verdes e brilhantes entre a vegetação murcha e triste, como no seio das misérias d'alma sorri um pensamento de esperança: - nestes tempos de desolação e indigência, a carnaúba é a amiga, e a companheira do pobre morador dos campos: - é ela que dá-lhe o sustento, porque estes homens rústicos soídos a viver à custa de seu braço e com o suor de seu rosto não sabem mendigar: - eles cortam as palmeiras pequenas que ainda rastejam pelo chão, e tiramlhe o miolo verde, tenro e composto de uma polpa amarelecenta: ${ }^{5}$ - este miolo é ralado como a mandioca; da massa extrai-se uma goma muito alva e agradável, preferível à araruta: - da polpa que resta fazem farinha que apesar de grossa supre maravilhosamente as necessidades urgentes daquele tempo: - desta árvore ainda os pobres aproveitam para alimento o fruto; - comem a massa exterior que é uma polpa negra semelhante à das tâmaras, e o caroço, que é oleoso, usam torrá-lo para tomá-lo à guisa de café: - é aromático e saboroso, e mais medicinal que o de Mocka. ${ }^{6}{ }^{7}$

\footnotetext{
4 Sem o hífen no original.

5 Preserva-se o termo original.

6 Nome de um porto iemenita de onde se exportava o café para o Ocidente. No Brasil tornou-se sinônimo do produto e ainda hoje é termo usado nas grafias moca e mooca.

7 Nesta última seca que houve no Ceará, o povo das vizinhanças da capital devastou em pouco mais de um mês uma várzea de carnaúba de 4 léguas de extensão, que há a alguma distância da cidade. [Nota de Alencar].
} 
A carnaúba serve para construções: - quando é cortada madura e posta sobre a coberta enxuta, dura séculos: - ainda hoje existem no Aracati casas de sobrado construídas de carnaúba, que datam da primeira povoação deste lugar: - e até agora não precisaram de reparos, nem consertos. Esta palmeira só por si basta à construção de uma casa: - ainda nestes tempos de agora se encontra amiúde por essas nossas várzeas e sertões do norte, muitas dessas casinhas campestres, singelas e rústicas, que são habitadas de gente pobre, e de índios: - são estas casinhas construídas com muita arte, e curiosidade. Os esteios e a cumeeira são tirados do tronco: - o teto é da palha tão bem arranjado que não se incomoda o morador com esses chuveiros temíveis que desabam sobre as campinas nos começos de inverno: - as paredes são construídas com ripas do tronco amarradas em xadrez, e entrelaçadas com palha para resguardo do tempo: - as folhas das janelas e da porta são feitas dos talos (pecíolos) arranjados com tal arte que não deixam frestas. E nestas casas todas construídas de carnaúba são ainda as lascas do tronco, ou a palha seca que arde no fogo, para cozinhar a ceia do lavrador que anda no seu trabalho: - e quando volta à noite, e à beira do fogo é sobre a esteira de carnaúba que ele descansa os membros fatigados.

E não são estas as únicas utilidades que presta esta palmeira: - nela nada se esperdiça, desde a raiz até o olho. - Do miolo quando seco, servemse para bengalas e outros misteres que envernizados são de lindo efeito pelo trançado das fibras negras que semelham a tartaruga. ${ }^{8}$ Da folha fazem-se esteiras, e vassouras, e da cortiça dos talos, rolhas para garrafas. - A palma quando ainda fechada ${ }^{9}$ tem pelos interstícios do leque uma camada de visgo branco, que se despega insensivelmente quando o leque começa a abrir: - é o que chamam - cera de carnaúba. - Para extraí-la cortam-se as palmas ainda fechadas, e depositam-se numa vasilha onde se possa colher o pó sutilíssimo, que vão despegando de si à proporção que secam. - A cera de carnaúba é fortíssima: - costumam derretê-la com duas partes de sebo, e aplicá-la ao fabrico de velas, que já são bem conhecidas no Comércio: - no Ceará onde se tem usado, e aperfeiçoado com algum proveito esta indústria, já conseguiram fabricar velas da cera pura da carnaúba, e estas

8 A raiz aplicam a usos medicinais, e é remédio para queixas de peito. [Nota de Alencar]. 9 No original: feixada. Esse termo, que volta a aparecer poucas linhas abaixo, parece dúbio, uma vez que pode ser também uma derivação do substantivo feixe construída sem o prefixo como seria o usual. 
são excelentes na luz, e pouco cedem ao espermacete, ${ }^{10}$ com a vantagem de durar muito mais; - são, na verdade, muito quebradiças, que a cera com ser demasiadamente forte, dá-lhes uma consistência vítrea e quase granítica.

A vida da carnaúba é longa de séculos; - a sua infância tardia evagarosa dura meio século. - À proporção que o tronco cresce os pecíolos secos lhe vão ficando agarrados como uma cercadura de espinhos, de modo que neste tempo o tronco representa ordinariamente uma grossura de 10 palmos. - aos 30 anos o crescimento para e começa o tronco a limpar-se, despegando os pecíolos secos: - quando o tronco está inteiramente nu e liso, a carnaúba é uma árvore secular. - Mesmo no nosso interior onde a vida do homem é extremamente dilatada, causa admiração quando alguém diz vendo uma carnaúba que já caduca de velha, e cujo olho começam a roer os periquitos: - aquela carnaúba eu vi nascer.

Caracteres botânicos. - Não nos foi possível à falta de tempo e instrumentos estudar todos os caracteres botânicos da carnaúba: - no tempo em que fizemos estas poucas observações, já havia passado de muito a época florescente desta palmeira: - no fruto colhemos alguns caracteres, os que nos era possível apreciar a olho nu; e uma das observações que houvemos por mais importante foi achar no fruto o ponto seminal, o que nos dava a conhecer o modo da procriação desta árvore, por que nem achamos quem nos informasse a este respeito nem pudemos fazer a experiência.

O tronco da carnaúba é lenhoso, - composto de fibras duras e entrelaçadas: - é liso e direito: - no estado de perfeito crescimento tem $3^{1 / 2}$ palmos de grossura e 50 de comprimento. - As folhas (Linn palma) são alequeadas, verdes, glabras, e lisas: - os pecíolos são corticosos, cobertos de espinhos, e chatos; tem 3 a 4 palmos de comprimentos e nascem em roda do olho da palmeira. - A raiz da carnaúba é fibrosa e emaranhada como a do Coqueiro (Linn radiae fibrata, retiformes): - suas fibras aliás muito finas (linearia) são bastante rijas e fortes, e se estendem em roda de um tronco num raio de 20 pés e mais: - a isso atribui-se com muita razão a existência sempre constante dessa palmeira em tempos de dilatadíssima seca quando passam ${ }^{11}$ sem chover 3 e 4 anos: - e é que sendo suas raízes muito longas e profundíssimas chupam maior porção de umidades do que

10 No original: espermacetti.

11 Singular no original. 
as outras árvores. - A essa contextura particular das raízes da carnaúba deve-se o ela viver sempre em terrenos sólidos e duros: - e esta qualidade pode ser aproveitada com imensa utilidade para consolidar o terreno nos caminhos, e estradas arenosos e fofos.

O fruto da carnaúba é pequeno e negro como uma ameixa, e tem a forma de uma cabacinha; dá em longas grinaldas de cachos que contém ordinariamente mais de cem frutas ligadas a uma haste que nasce do olho da palmeira. - O pericarpo (drupa) é negro e polposo, e adocicado coberto de uma casca áspera e granítica, contida numa película fina, lisa e glabra. - Dentro do pericarpo se contém a semente: a semente é caroço (nux): este caroço contém três tegumentos próprios bem distintos à vista: - o primeiro - (o externo) é um casulo duro, granítico, quebradiço, muito grosso à proporção dos outros; tem a cor esbranquiçada; é de forma oval, formando na ponta um embigo com 3 capsulazinhas por onde deve germinar a plântula seminal; - o segundo (vesícula) é uma membrana finíssima e transparente, macia e sulcada por diversas veias esverdeadas: - está ligada ao $3^{\circ}$. tegumento interno que rodeia os cotilédones: - este é uma massa esverdeada umedecida por um humor gelatinoso que penetra até o âmago dos cotilédones por certas incisões particulares. - A medula da semente é alva, adstringente, amargosa e compacta. $-^{12}$

Al. (Sócio Corresp.)

12 Cumpre-nos notar, para não faltar a exatidão que estas observações foram feitas sobre frutos que ainda não estavam completamente maduros. [Nota de Alencar]. 


\section{TRAÇOS BIOGRÁFICOS SOBRE A VIDA DE Dom Antônio Felipe CAMARão}

Não vai talvez grande mérito no recopilar a história, e extrair dela uma biografia. - Tenho que será de utilidade recadar as folhas carcomidas dos cronistas de nossos tempos coloniais, de comum pouco lidos e considerados, os fatos importantes, e as cousas grandes de um homem que nos merece gloriosas recordações: - e nesta fé escrevo de vontade.

Quando a pena hábil de escritores de nota, se ocupou em desenhar a figura histórica dos Brasileiros distintos que se haviam unido ao progresso das letras, tive por grave descuido deixar-se muda, eadormecida no fundo das tradições nacionais, o vulto guerreiro desse índio, que se revelava um $^{13}$ caráter tão belo: - e levado destas considerações, dei-me a escrever esta biografia, que talvez só tem o mérito acidental de espalhar na nossa literatura moderna, ligeiros relevos de nossas reminiscências indígenas, às vezes tão de mais desprezadas, às vezes tão acrescentadas que menos parecem esquecidas tradições dos tempos já idos que caracteres da vida presente.

Não é de saber pelos homens lidos e estudados nas cousas do Brasil, que a guerra dos holandeses na capitania de Pernambuco, é a página brilhante em que anda inscrita com feitos e ânimos esforçados, a vida de D. Antônio Felipe Camarão: - nem há aí na história pátria fato desta guerra, que se autorize de grande e heroico, que não tenha o cunho do seu nome. - Filho das crenças dos índios, ele renegou sua vida de selvagem liberdade às primeiras palavras dos ministros da religião, - e se fez cristão. - Há neste fato espaço a sérios pensamentos. - Porém deixemos a religião de Cristo sua angélica majestade, o brilho incendido de suas tradições. - É$^{14}$ o destino de Deus: - diremos somente que para compreender de simples intuição tanta sublimidade, eram necessários grandes instintos, grande inteligência: - e nisso vai glória ao homem, que a nós historiador não é cabível ${ }^{15}$ esquecer.

Antônio Camarão foi homem de boas virtudes no serviço de Deus, de valentes brios na causa do Rei: - do seu ânimo esforçado, e da sua

13 No original: u'um.

14 Minúscula no original.

15 No original: cabi [mancha] lo. 
fidelidade não há falar: tanto era sabido em haver-se com denodo nos combates, como autorizado no concelho, e muito entendido no que era arte da guerra. - Nele a coragem e a prudência corriam sempre o páreo qual a valer em tempo oportuno. $\mathrm{De}^{16}$ maneira que se no ataque era ardente e impetuoso, na retirada fazia-se refletido e cauteloso. Não se negava do que era, e do que devia à defesa de seu Rei: - e tinha sempre acatamento guardado à dignidade das pessoas que os prejuízos daquele tempo haviam colocada em plaina superior: - e com isso se fazia respeitar, que aquele é mais respeitado, que melhor sabe guardar o respeito. - Havia por costume não falar a pessoas autorizadas na língua portuguesa, em que era muito versado, mas na língua indígena por meio de intérpretes.

Na guerra contra os holandeses outros homens partilharam com Camarão as palmas desta luta gloriosa da independência das colônias; - ninguém as cobrou mais. - Muitos atacavam com ele, nem um se defendia com tanta perícia e juízo tão acertado: - muitos pelejavam à sua conta e no serviço do Rei, poucos como ele se esforçaram na defesa da Pátria e da Religião: - e um só como ele entrou nesta guerra sem interesses do mundo. $\mathrm{E}^{17}$ subiu tão alto, que era verdadeiro contraste medir-se o que ia do estádio de onde saíram, à posição que conquistaram a troco de inteligência e coragem: - e este foi Henrique Dias. ${ }^{18}$

Das qualidades e virtudes de Camarão, fazem larga menção os escritores da guerra holandesa: - e o seu elogio anda escrito com créditos de história, e força de estilo nestas palavras autorizadas de Fr. Rafael de Jesus - no Castrioto Lusitano:19

Em servir a coroa, e a Igreja ganhou luzido crédito de soldado e de religioso; e tão observante de suas obrigações, que nunca o viu distraído, quem sempre o venerou soldado. - Gastava muitas horas na oração a que se aplicava ainda

16 Minúscula no original.

17 Minúscula no original.

18 Depois de concluído este nosso trabalho, contamos dar à estampa a biografia de Henrique Dias: - talvez a crítica nos culpe de manias por estas cousas velhas e antiquadas: - carregaremos de bom grado com a inculpação, porque nesta época em que vamos vivendo, em que tanto se espera do futuro, em que o modernismo é tudo, não será debalde que sejamos estudados nas cousas velhas, porque estas antiguidades [sic] que realmente são, se tornarão novidades. [Nota de Alencar]. No original está grafado antiquidade por antiguidade.

19 No original, a longa citação que segue aparece, como era usual à época, integrada ao texto, destacada tão somente por discretas aspas no início e final.2o Emquanto, no original. 
nos maiores estrondos da guerra; - para sair aos rebates, e para entrar nas batalhas primeiro se fortalecia com o sacramento, que com as armas: - nas ocasiões mais arriscadas recorria ao favor divino de duas imagens do Senhor e da Senhora, que entres as roupas trazia de contínuo sobre o peito. Enquanto ${ }^{20}$ soldado não houve capitão mais amado, nem mais obedecido, ${ }^{21}$ por que não houve capitão que achasse mais império na afabilidade, que no domínio, do que este valoroso capitão. - As empresas o esperavam sempre com as vitórias; e ganhou tantas vitórias quantas foram as ocasiões em que pelejou. - Para seu gênio era o ócio martírio, e o trabalho descanso: - avaliava a penalidade por deleite, e as ocasiões por dita. - Seu nome, como memorial de suas proezas se ouvia entre os nossos com respeito, e entre os inimigos com espanto: - e dilatou-o de sorte a fama, que chegou aos ouvidos do seu Rei tão distante, quanto o apartavam os dilatados mares, que dividem a América da Europa. - Sem petição o despachou seu merecimento. - Deu-lhe El-Rei Felpe IV, o hábito de Cristo, o título de Dom, e o posto de Governador e Capitão Geral de todos os índios da América. ${ }^{22}$

$$
\mathbf{2}^{\mathrm{O}}
$$

O que levamos dito das grandes cousas que fez Camarão, vão à conta de biógrafo: - aos olhos do historiador que procura nos mistérios do passado, o germe criador dos tempos futuros, Camarão é mais que um homem distinto, e um tipo histórico.

Nos tempos coloniais, haviam dois elementos de colonização, que se excluíam mutuamente no seu desenvolvimento geral: - era o elemento militar, e o elemento religioso: - a guerra e a missão. - Defeitos e bem grandes cresciam com a realização exclusiva destes dois princípios.

Os missionários jesuítas, e os outros que os tinham por modelo na prática da Religião, eram em demasia severos e rígidos: - não cuidavam de proceder na catequese dos índios lenta e gradualmente, como era de razão, e tinham por vantagem a brevidade, como se para Deus, o tempo fosse em alguma cousa. - Seu pensamento de civilização se consumava no tempo breve, na condição fraco: - o Índio passava de uma vida selvagem a um a vida social sem transição, e saía das matas com o passo

20 Emquanto, no original.

21 Odedecido, no original.

22 Segundo Brito Freire na "Guerra Brasílica” também fez-lhe El-Rei Felipe IV mercê da Comenda da Ordem de Cristo, e do foro de fidalgo. [Nota de Alencar]. O Castrioto lusitano está disponível para leitura e download em: http://www2.senado.leg.br/bdsf/ item/id/179485. Visitado em 3 de julho de 2016. 
com que entrava na cidade. - $\mathrm{O}$ mal que resultava disto, não hei mister dizer: - os missionários faziam com a palavra, e desfaziam com a ação, como se Deus falara inspirações por sua boca, e o homem obrara erros à sua conta.

O elemento militar era guerra: - então a destruição fazia a vez de pregação, o sangue a vez de batismo. - Se um pensamento superior fosse em alguma cousa no acordo destes dois princípios, com a destruição do que havia neles de mal, um elemento regenerador, cheio de seiva ealento, nasceria daí: nossa vida de hoje seria uma mocidade forte e vigorosa, e não sofreríamos da infância esses achaques de decrepitude que a velha Europa nos herdou. ${ }^{23}$ - Porém, como é sabido, as cousas do Brasil, sempre correram em muito desprezo no ânimo dos Reis de Portugal. - O elemento militar dominou: - destruiu-se uma nação valente e guerreira, inteligente e industriosa em guerra exterminadora, às vezes iníqua e traiçoeira; - o Brasil comprou a sua colonização com o sangue dos seus filhos, com o ouro de suas entranhas. - No desenvolvimento da história todos estes princípios que marcam uma revolução têm uma ação e uma reação: - a ação é um fato consumado, já ido, entrado no domínio da história, e sujeito a juízo da posteridade: - julgamos dele. - A (re)ação é um fato contemporâneo em que se envolvem os homens da geração presente: - neste nos calamos e esperamos: - o futuro decidirá.

Algumas vezes o princípio religioso fugia à ação do elemento destruidor da guerra: - o missionário fazia-se a sertões a dentro, e a palavra santa da Religião conquistava uma alma a Deus, um homem à civilização, um cidadão à pátria: - o Índio inteligente e bravo trazido à sociedade, copiava a sua vida pelo exemplo dos homens virtuosos.

Camarão é o representante desses homens regenerados, é o tipo do Índio civilizado.

Graves considerações e profundas deve despertar este fato a quem sujeitar à crítica a história do nosso país. - Nós o apontamos simplesmente, e deixamos ao historiador, o seu desenvolvimento.

S. Paulo, 20 de maio de $1849 .^{24}$

Alencar.

(Continuar-se-á.)

23 Sic.

24 No original: S, Paulo 20 de Maio de 1849. 


\title{
O ESTILO NA LITERATURA BRASILEIRA
}

\author{
Expressão do Estilo. - Estilo clássico e \\ quinhentista. Estilo moderno. - Renascimento \\ do estilo quinhentista: - Filinto Elísio. - \\ Escritores portugueses modernos: Castilho \\ - Garrett - A. Herculano - Mendes Leal. - \\ Galicismos. Fr. Francisco de S. Luís. - Escritores \\ Brasileiros. - Qual o estilo que se harmoniza \\ mais com a nova literatura.
}

A palavra é a reflexão, o eco do pensamento: - na nossa língua portuguesa, tão rica de expressão, ela reveste as ideias de uns toques suaves, de uma melodia sonora que encanta: - e os lábios acham certo prazer indefinido em repetir a frase doce e maviosa de um escritor de bonito estilo. Sua alma se mira enlevadamente na dicção, e dá-lhe uma expressão íntima e verdadeira: suas palavras parecem sorrir docemente com os enleios do coração, palpitar com as incertezas, suspirar tristemente com as mágoas e aflições, e sua frase é singela e meiga como o perfume dos sentimentos doces, ou solene e ardente como os ecos das paixões fortes e veementes. Há escritores que meneiam tão bem a palavra, que materializam nos seus acentos a expressão, o tom do pensamento. Garrett ${ }^{25}$ falando do estilo da poesia disse: "Imitar com o som mecânico das vozes a harmonia íntima da ideia, suprir com as vibrações que só podem ferir a alma pelo órgão dos ouvidos, a vida, o movimento, as cores, as formas dos quadros naturais, eis aí a superioridade da poesia, a vantagem que tem sobre todas as outras belas artes: - mas, quão difícil é perceber e executar esse delicadíssimo ponto!"26

Nem são elas as únicas vantagens do estilo: - ele favorece muito a compreensão, e fácil inteligência das ideias. - Quando lemos uma obra escrita em lindo estilo, em dicção pura e corrente o espírito parece que se abre espontaneamente sem esforço e sem meditação à percepção do pensamento, às aspirações do sentimento: a imaginação se embala deliciosamente na cadência de frase; e as ideias revestidas dessa forma encantadora, dessa auréola de palavras belas e sonoras se gravam com maior facilidade na memória, e mais custam esquecer.

25 Trata-se do escritor Almeida Garrett; no original aparece todas as vezes Garret. 26 GARRETT. Obras completas, 1904, v. II, p. 359. 
A língua portuguesa degenerada pela invasão dos Mouros na Península, começou a depurar-se no século $15^{\circ}$ - O cultivo das línguas clássicas introduzido com a reformulação da Universidade de Coimbra em tempos do reinado do Senhor Rei D. João $3^{\circ}$, contribuiu muito para o aperfeiçoamento da língua. ${ }^{27}$ Foi o tempo de mais brilhantes glórias literárias de Portugal: - As obras clássicas de J. de Barros, Diogo Couto, Azurara, Lucena, Arraes, Fr. Heitor Pinto, Camões e Ferreira, ${ }^{28}$ são em abono do que dizemos.

O estilo destes escritores, comumente chamado estilo quinhentista, ${ }^{29}$ é considerado como o verdadeiro, puro e clássico da língua portuguesa. Não somos estudados nesses clássicos de nossa língua, quanto era de nossa vontade para os analisarmos especialmente no seu estilo: - apelamos para o que a respeito escreveram penas de mestres..$^{30}$ Alguma cousa que temos lido nestes mestres da língua, nos chegou para colher do estilo da literatura do $15^{\circ}$ século a sua feição geral, seus tons e cores locais, e sua expressão pura e genuína, e essa solenidade clássica ${ }^{31}$ que lhe dá um cunho de nacionalidade.

O estilo quinhentista élento e truncado: - seus períodos arredondados ao modo latino, encadeiam numa fórmula breve, rápida e concisa o pensamento, e não lhe permite dar largas a todo o seu desenvolvimento: sua frase é solta, e desligada, e falta-lhe esta ondulante flexibilidade, essa expressão abundante e rica do estilo moderno que desenha todos os tons, todas as nuanças ${ }^{32}$ do pensamento. Mas em compensação há nesse modo

27 Bosquejo de história da poesia e língua portuguesa. [Nota de Alencar]. Trata-se da obra de Garrett, incluída nas suas Obras completas

28 João de Barros, gramático e historiador, autor das Décadas; Diogo de Couto, historiador, escreveu a continuação das Décadas; Gomes Eanes de Azurara (ou Zurara), cronista do século 15; Padre João de Lucena, autor da História da vida de São Francisco Xavier, considerado um mestre pela linguagem castiça; Frei Amador Arrais, bispo de Portalegre (Beja), autor dos Diálogos (iniciados por seu irmão); Frei. Heitor Pinto, autor de $A$ imagem da vida cristã; Luís Vaz de Camões, poeta, autor de poesia lírica e do épico Os lusíadas; Antônio Ferreira, poeta e humanista, autor dos Poemas lusitanos e de uma tragédia famosa, A Castro. São todos apontados como grandes mestres da língua portuguesa escrita nos séculos 15 e 16.

29 Todos os itálicos estão no original.

30 Felinto Elísio - na sua Arte poética - e Garrett - na História da língua portuguesa. [Nota de Alencar].

31 Garrett. [Nota de Alencar].

32 Esta palavra é francesa, e reprovada por Francisco Manuel: - porém a necessidade a tem admitido em nossa língua, e eu uso dela, com a autoridade de Fr. Francisco de S. Luís, no seu Glossário. [Nota de Alencar]. 
de escrever um caráter de solenidade sublime: essa mesma fórmula curta em que ele enclausura o pensamento, parece concentrar todas suas forças numa expressão de energia admirável: sua expressão é solta e truncada, mas cheia dessa simplicidade majestosa e doce da frase bíblica, - sua palavra forte e severa respira os acentos propendos dessa fé austera, dessa convicção inabalável dos homens antigos.

Há no estilo moderno, uma fluidez, uma elasticidade admirável: - a frase corre solta com o pensamento, e se expande em toda a sua força de expressão, em todas as suas linguagens: - a imaginação se retraça ao vivo cismas e enlevos na vivacidade, na animação da frase moderna.

Entre esses dois estilos, qual escolher, como mais conveniente para refletir a expressão de nossa literatura?

O estilo antigo não pode renascer em nossa literatura brasileira com suas cores, seus tons clássicos: - nascido nos tempos da fé, heroísmo dos Portugueses, ele conservou essa forma imóvel e inflexível das crenças profundas, das convicções inabaláveis: - naquela época de certo dera ela a expressão aberta do pensamento. Hoje as ideias caminham delirantes, várias, e desvairadas, não se poderiam conter na fórmula rápida, breve do período antigo: - e além disso a expressão ardente e animada de nossa literatura não casa com essa lenta e pausada inflexão da frase antiga. Nunca a dicção do estilo quinhentista poderia exprimir com a doce facilidade do espírito, uma cena encantada de nossa terra, um suave retiro de nossas florestas, uma tarde pura de nossos céus, com esses tons maviosos, com esses timbres sonoros que lhe reflete o sol descaindo no ocidente: - a precisão de elocução antiga martirizaria os enlevos de nossas almas, nossas diversas inspirações entusiásticas, profundas como o seio de nossas florestas, e como os abismos de nossas montanhas, inquietas, e delirantes como o menear das orlas de nossas moitas: - a frase clássica gelaria os toques abrasados de nossa poesia ardente, vacilante, e com a frieza de austeridade de sua palavra rígida e severa.

Não vamos entretanto com aqueles que desprezam por demais o estilo quinhentista, e o têm em esquecimento profundo. Ele encerra muitas belezas, muitas elegâncias de nossa língua portuguesa, que renascida com esmero e cuidado, dará ao estilo moderno um encanto supremo. Há frases cheias de bela singeleza e naturalidade, palavras doces e suaves que parecem materializar o pensamento, e que desvanecem a imaginação de encanto. - E nas flores mimosas da língua podem ainda verter perfumes, 
embalsamados com os ardores de nossa poesia, coloridos com a expressão brasileira tão vivaz e tão brilhante.

Ainda em alguns casos o estilo antigo pode ser bem aceito. Há certos gêneros de composição literária, em que a expressão desse estilo reveste o pensamento e as ideias de uma cor antiga e austera, e como que emprestarlhe o respeito, e autoridade das cousas velhas.

Nossas crônicas, nossas tradições de tempos coloniais devem ser escritas nesse estilo: - até mesmo seria natural e encantador apreciar os contrastes desse estilo, com a expressão indígena. - Castilho escreveu suas poesias na dicção moderna, porém escolheu para os seus Quadros Históricos, a expressão severa com que falavam aqueles homens que ele pintava: - ele constituía-se como órgão que refletia só ecos das palavras.

Alencar.

(continua) 